\title{
STUDIES ON GASTROINTESTINAL EFFECTS OF DESMODIUM VELUTINUM: A TRADITIONAL REMEDY FOR DIARRHEA
}

\author{
Ezike, A.C., P.A. Akah, C.O. Okoli, I.K. Ufere, \\ E. Ezeudu, C.F. Okoye, C. Ashara and I.N. Igbokwe \\ Department of Pharmacology and Toxicology, \\ Faculty of Pharmaceutical Sciences, University of Nigeria, Nsukka, 410001, Enugu State, Nigeria
}

Received 2013-11-26; Received 2014-01-20; Accepted 2014-03-12

\begin{abstract}
The gastrointestinal and antibacterial properties of dichloromethane: Methanol extract (DVE) and fractions (DVHF, DVDF and DVMF) from Desmodium velutinum Willd. DC. (Fabaceae) leaves were investigated. The extract and fractions significantly $(\mathrm{p}<0.05)$ reduced normal defecation in rats $(33-100 \%)$ and significantly $(\mathrm{p}<0.05-0.001)$ protected rats against castor oil- induced diarrhea $(40-100 \%)$. They significantly $(\mathrm{p}<0.05)$ prolonged the intestinal transit time of charcoal meal in mice and inhibited the spontaneous contractions of the isolated rabbit jejunum and acetylcholine- and histamine-induced contractions of the guinea pig ileum. They potently protected against ethanol and mildly against indomethacin-induced gastric ulcers. Only DVE inhibited the growth of Bacillus cereus, Pseudomonas aeruginosa, Escherichia coli and Salmonella typhi with MICs of 37.15, 39.81, 100 and $100 \mathrm{mg} \mathrm{mL}^{-1}$ respectively. Acute toxicity test on DVE established an oral $\mathrm{LD}_{50}>5 \mathrm{~g} \mathrm{~kg}^{-1}$ in mice. Results demonstrated that $D$. velutinum leaf possesses gastrointestinal antimotility and antispasmodic effects and mild antibacterial and gastroprotective activities.
\end{abstract}

Keywords: Desmodium Velutinum, Antispasmodic, Gastrointestinal Motility, Guinea Pig Ileum, Rabbit Jejunum

\section{INTRODUCTION}

Diarrhea is passage of abnormally liquid or unformed stools at an increased frequency (Ahlquist and Camilleri, 2005). It involves an increase in the fluidity, volume and frequency of bowel movements accompanied by increased secretion and decreased absorption of fluid and thus, loss of water and electrolytes (Spruill and Wade, 2005). Generally, an imbalance in the absorptive and secretory mechanisms in the intestinal tract, accompanied by hypermotility results in diarrhea. Available estimates suggest that about 4.6 million people, including 2.5 million children, particularly in developing countries, die from diarrhea every year (Kosek et al., 2003; Thapar and Sanderson, 2004). Consequently, management of diarrhea is of immense public health importance.

In many regions of Africa, the use of plants in the treatment of diarrhea is common practice due largely to their ease of availability and proven effectiveness. Among such medicinal plants is the popular southeast Nigerian antidiarrheal remedy, Desmodium velutinum (Wild.) D.C. (Fabaceae, alt. Leguminosae). D. velutinum is a perennial shrub native to tropical Africa and subtropical Asia (China, Taiwan, India, Indonesia, Laos, Malaysia, Myanmar, Sri Lanka, Thailand and Vietnam). Corresponding Author: Ezike, A.C., Department of Pharmacology and Toxicology, Faculty of Pharmaceutical Sciences, University of Nigeria, Nsukka 410001, Enugu State, Nigeria Tel: +2348052820538 
It is commonly found in the Savannah, along road sides and in clearings from Senegal to Nigeria and from Cameroun to Angola and also in Sudan (Asare et al., 1984). It grows up to $3 \mathrm{~m}$ high; the velutinous (velvety) surface of its 1 -foliloate leaf is a characteristic feature. It grows well on soil with $\mathrm{pH}$ of 4.0 to alkaline and prefers high rainfall (1000 to $>3000 \mathrm{~mm}^{3} /$ year), but tolerates up to five dry months (Akinola et al., 1991). Its morphology has been described (Akinola et al., 1991).

In Nnobi community of Anambra State, Nigeria, the aqueous extract of the fresh leaves is warmed and administered orally to stop diarrhea. Its acclaimed antidiarrheal efficacy earned it the vernacular name "Uchu gba ohu", literally translated to mean "may the anus be cursed". In Okpaligbo, Enugu State, Nigeria, the leaves are chewed and the juice swallowed as a remedy for diarrhea. Elsewhere, juice squeezed from the pounded leaves is mixed with local chalk and taken for treatment of diarrhea. D. velutinum is also used in traditional medicine as antipyretic and analgesic and consumed as food due to its nutritive value. In Nnobi, it also serves as an ingredient of a charm used to capture thieves.

Earlier studies demonstrated the antipyretic activity of the plant (Anowi et al., 2012a), also intraperitoneal administration of the methanol: Methylene chloride leaf extract was shown to reduce intestinal motility (Anowi et al., 2012b).

This study evaluated the antidiarrheal properties of D. velutinum leaf extract and fractions in murine models of diarrhea and gastrointestinal motility, as well as antispasmodic action in isolated tissue preparations. We also evaluated the antibacterial activity of the extract and fractions and their effects on experimentally induced ulcers in rodents.

\section{MATERIALS AND METHODS}

\subsection{Chemicals and Reagents}

Dichloromethane, methanol and ethanol (Sigma Aldrich, Germany).

\subsection{Drugs}

Atropine, acetylcholine, histamine, indomethacin and castor oil were purchased from Sigma Aldrich, Germany. Loperamide was purchased from Janssen Pharmaceuticals Incorporated, U.S.A.

\subsection{Animals}

Adult Swiss albino rats (150-200 g) and mice (19-22 $\mathrm{g})$ as well as adult guinea pigs (350-400 g) and rabbits of either sex bred in the laboratory animal facility of the Department of Pharmacology and Toxicology, University of Nigeria, Nsukka were used for the study. The animals were maintained freely on standard pellets and water. All animal experiments were in compliance with National Institute of Health Guide for Care and Use of Laboratory Animals (Pub No. 85-23, revised 1985).

\subsection{Plant Material}

Fresh leaves of $D$. velutinum were collected in December at Ede Orba, Nsukka L.G.A. of Enugu State and authenticated by Mr. Alfred Ozioko of the International Centre for Ethnomedicine and Drug Development (InterCEDD) Nsukka, Enugu State, where a voucher specimen was deposited (specimen number: INTERCEDD 097). The leaves were dried under shade for 3 days and reduced to coarse powder using an electric grinder.

\subsection{Extraction and Fractionation}

The powdered plant material $(4.2 \mathrm{~kg})$ was macerated in a mixture of dichloromethane and methanol (1:1) for $48 \mathrm{~h}$ at room temperature $\left(25 \pm 2^{\circ} \mathrm{C}\right)$. The mixture was filtered and the filtrate concentrated with a rotavapor under vacuum $\left(40^{\circ} \mathrm{C}\right)$ to afford $620 \mathrm{~g}$ of the extract (DVE; $14.76 \%$ w/w). The DVE $(200$ g) was fractionated in a silica gel (Silica gel 60, 70-230 Mesh ASTM) column successively eluted with n-hexane, dichloromethane and methanol $(100 \%)$ to obtain the hexane (DVHF; $50 \mathrm{~g} ; 25 \% \mathrm{w} / \mathrm{w}$ ), dichloromethane (DVDF; $25 \mathrm{~g} ; 12.5 \% \mathrm{w} / \mathrm{w}$ ) and methanol (DVMF; 90 $\mathrm{g} ; 45 \% \mathrm{w} / \mathrm{w})$ fractions. The fractions were then concentrated in a rotavapor under vacuum and stored at $-4^{\circ} \mathrm{C}$ in a freezer.

The extract and fractions were subjected to phytochemical analysis for preliminary identification of constituents using standard procedures (Harborne, 1973; Iwu, 1978; Trease and Evans, 1996).

\subsection{Acute Toxicity and Lethality $\left(\mathrm{LD}_{50}\right)$ Test}

The acute toxicity and lethality of DVE was determined using the method described by Lorke (1983). Briefly, nine mice randomly divided into three groups $(n=3)$ were orally administered 10, 100 and $1000 \mathrm{mg} \mathrm{kg}^{-1}$ of the extract respectively and observed for $24 \mathrm{~h}$ for death. Since no death was recorded, $1,600,2,900$ and $5,000 \mathrm{mg} \mathrm{kg}^{-1}$ of the extract were administered to a fresh batch of animals at one animal per dose; the number of deaths in $24 \mathrm{~h}$ was recorded. 


\subsection{Normal Defecation Test}

The effect of the extract and fractions on normal defecation was studied using a modification of the method described by Izzo et al. (1992). Rats fasted for $18 \mathrm{~h}$, but allowed free access to water were randomly grouped $(n=5)$ to receive oral administration of one of DVE (200 or $400 \mathrm{mg} \mathrm{kg}^{-1}$ ), DVHF (200 or $400 \mathrm{mg} \mathrm{kg}^{-1}$ ), DVDF (200 or $400 \mathrm{mg} \mathrm{kg}^{-1}$ ) or DVMF (200 or $400 \mathrm{mg}$ $\mathrm{kg}^{-1}$ ) respectively. Control groups received the vehicle [mixture of $15 \%$ tween 80 and propylene glycol (1:1)] (5 $\left.\mathrm{mL} \mathrm{kg}{ }^{-1}\right)$, or loperamide $\left(2 \mathrm{mg} \mathrm{kg}^{-1}\right)$. The rats were placed in individual metal cages and feces were allowed to collect on white paper placed on trays beneath the cages. The fecal matters were easily observed by lifting off the trays. The number of fecal boli produced by each animal was recorded every hour for $4 \mathrm{~h}$.

\subsection{Castor Oil-Induced Diarrhea Test}

A modification of the method of Awouters et al. (1978) was adopted. Rats fasted for $24 \mathrm{~h}$, but allowed free access to water were randomly grouped $(n=5)$ to receive oral administration of one of DVE (200 or 400 $\mathrm{mg} \mathrm{kg}{ }^{-1}$ ), DVHF (200 or $400 \mathrm{mg} \mathrm{kg}^{-1}$ ), DVDF (200 or $400 \mathrm{mg} \mathrm{kg}^{-1}$ ) or DVMF (200 or $400 \mathrm{mg} \mathrm{kg}$ ) respectively. Control groups received the vehicle [mixture of $15 \%$ tween 80 and propylene glycol (1:1)] $\left(5 \mathrm{~mL} \mathrm{~kg}^{-1}\right)$, or loperamide $\left(2 \mathrm{mg} \mathrm{kg}^{-1}\right)$. One hour after treatment, each rat received $2 \mathrm{ml}$ castor oil (p.o). The rats were placed in individual metal cages and the fecal matters were easily observed by lifting off the trays underneath the cages. The following parameters were recorded every hour for $5 \mathrm{~h}$; time between the administration of castor oil and the excretion of the first diarrheic (wet) stool, total number of fecal output and the number of wet stool excreted.

\subsection{Gastrointestinal Motility Test}

The effect of the extract and fractions on intestinal propulsion was determined using the charcoal meal test (Akah, 1989), with slight modifications (Ezike et al., 2009; 2011). Swiss albino mice fasted for $24 \mathrm{~h}$, but allowed free access to water were randomly grouped $(\mathrm{n}=$ 5 ) to receive oral administration of one of DVE (200 or $400 \mathrm{mg} \mathrm{kg}^{-1}$ ), DVHF (200 or $400 \mathrm{mg} \mathrm{kg}^{-1}$ ), DVDF (200 or $400 \mathrm{mg} \mathrm{kg}^{-1}$ ) or DVMF (200 or $400 \mathrm{mg} \mathrm{kg}^{-1}$ ) respectively. Control groups received the vehicle [mixture of $15 \%$ tween 80 and propylene glycol (1:1)] (5 $\left.\mathrm{mL} \mathrm{kg}{ }^{-1}\right)$ or atropine $\left(10 \mathrm{mg} \mathrm{kg}^{-1}\right)$. Thirty minutes later, charcoal meal (5\% activated charcoal suspended in $10 \%$ aqueous solution of tragacanth powder) was administered orally to each animal. The animals were sacrificed in a chloroform chamber $30 \mathrm{~min}$ after administration of the charcoal meal and the abdomen cut open. The small intestine of each animal was carefully identified (to avoid disruption of the charcoal meal during handling) and the distance traversed by the charcoal meal from the pylorus was measured. Also, the distance from the pylorus to the ileocecal junction (length of the small intestine) was measured. The extent of intestinal propulsion (\%) of the charcoal meal was calculated using the relation:

$$
\mathrm{IP}(\%)=(\mathrm{DT} / \mathrm{TL}) 100
$$

Where:

IP = Intestinal propulsion

DT $=$ Distance traversed by the charcoal meal and

$\mathrm{TL}=$ Total length of the small intestine

Inhibition (\%) of propulsion was calculated relative to control using the relation:

$$
\text { Inhibition of propulsion }(\%)=100[1-(\mathrm{a} / \mathrm{b})]
$$

Where:

$\mathrm{a}=$ IP of treated animals and

$\mathrm{b}=\mathrm{IP}$ of control animals

\subsection{Studies on Isolated Guinea Pig Ileum}

This was done as previously described (Ezike et al., 2011). Guinea pigs were sacrificed by cervical dislocation and bled. A segment of the ileum was removed after discarding the portion nearest to the ileocecal junction. The ileal strip (approximately $2 \mathrm{~cm}$ in length) was mounted vertically under resting tension of $0.5 \mathrm{~g}$ in a $50 \mathrm{~mL}$ organ bath. The tissue bathing fluid was Tyrode solution of the following composition (g/L) $\mathrm{NaCl}(8.0), \mathrm{KCl}(0.2), \mathrm{CaCl}_{2}(0.2)$, $\mathrm{NaHCO}_{3}$ (1.0), $\mathrm{MgCl}_{2}$ (1.0), $\mathrm{NaH}_{2} \mathrm{PO}_{4}(0.5)$, glucose (1.0); which was maintained at $37^{\circ} \mathrm{C}$ and aerated with air. The tissue was allowed to equilibrate for $60 \mathrm{~min}$ during which the bathing fluid was changed every 10 min. Responses of the isolated ileum to graded concentrations of DVE, DVHF, DVDF, DVMF, acetylcholine and histamine were recorded isometrically using an Ugo Basile Unirecorder (7050) through Ugo Basile isometric transducer (7004). Drug tissue contact time was 1 and a 3 min time cycle was maintained.

Also the effects of the extracts and fractions on acetylcholine $\left(0.64 \mu \mathrm{g} \mathrm{mL} \mathrm{m}^{-1}\right)$ - and histamine $(0.64 \mu \mathrm{g}$ $\mathrm{mL}^{-1}$ )-induced contractions of the guinea pig ileum respectively were recorded. The extract or fraction was added to the tissue bath and allowed to act for $3 \mathrm{~min}$; 
subsequently, the standard agonist was added and allowed to act for $1 \mathrm{~min}$ before washing off. The experiments were performed in triplicates using ileum from different animals.

\subsection{Studies on Isolated Rabbit Jejunum}

Rabbits were sacrificed by cervical dislocation and bled. The stomachs were removed and segments of the jejunum (about $2 \mathrm{~cm}$ long) removed and dissected free of mesenteric attachments. The jejunal strip was mounted vertically under resting tension of $0.5 \mathrm{~g}$ in a $50 \mathrm{~mL}$ organ bath. The tissue bathing fluid was Tyrode solution maintained at $37^{\circ} \mathrm{C}$ and aerated with air. The tissue was allowed to equilibrate for $60 \mathrm{~min}$ during which the bathing fluid was changed every $10 \mathrm{~min}$. Responses of the isolated tissue to graded concentrations of DVE, DVHF, DVDF and DVMF were recorded isometrically using an Ugo Basile Unirecorder (7050) through Ugo Basile isometric transducer (7004). Drug tissue contact time was I min and a 3 min time cycle was maintained. The experiments were performed in triplicates using jejunum from different animals.

\subsection{Absolute Ethanol Induced Ulcer}

Ulceration was induced as described by Robert (1979). Swiss albino rats fasted for $24 \mathrm{~h}$, were randomly grouped $(n=5)$ to receive oral administration of 200 or $400 \mathrm{mg} \mathrm{kg}^{-1}$ of DVE, DVHF, DVDF or DVMF respectively. Control groups received the vehicle [mixture of $15 \%$ tween 80 and propylene glycol (1:1)] (5 $\left.\mathrm{mL} \mathrm{kg}{ }^{-1}\right)$, or cimetidine $\left(100 \mathrm{mg} \mathrm{kg}^{-1}\right)$. Thirty minutes later, ulcer was induced by oral administration of absolute ethanol $(1 \mathrm{~mL})$ to all the animals. An hour later, the animals were sacrificed by overdose of chloroform anesthesia and the abdomen cut open. The stomach of each animal was removed, opened along the greater curvature, rinsed under a stream of water and observed for ulcers. Erosions formed on the glandular portion of the stomach were observed and each stomach given severity rating on a 0-7 scale based on the ulcers. Where $0=$ no ulcer, $1=$ One slight ulcer, $2=$ More than one grade 1 ulcer, $3=$ One ulcer of length $\leq 0.5$ $\mathrm{cm}, 4=$ One ulcer of length $>0.5 \mathrm{~cm}, 5=$ More than one grade 3 ulcer, $6=$ More than one grade 4 ulcer, 7 = Complete hemorrhagic lesion of the mucosa. Mean ulcer score for each group was calculated and expressed as the Ulcer Index (UI). Ulcer protection (\%) was calculated using the relation:

$$
\text { Ulcer protection }(\%)=100[1-\mathrm{y} / \mathrm{z}]
$$

Where:

$\mathrm{y}=$ Ulcer index of treated group

$\mathrm{z}=$ Ulcer index of control group (Ezike et al., 2009)

\subsection{Indomethacin Induced Ulcer}

Ulceration was induced as described by Urishidani et al. (1979) with slight modifications (Ezike et al., 2009). Rats fasted for $24 \mathrm{~h}$ were randomly grouped $(n=5)$ to receive oral administrations of 200 or $400 \mathrm{mg} \mathrm{kg}^{-1}$ of DVE, DVHF, DVDF or DVMF respectively. Control groups received the vehicle [mixture of $15 \%$ tween 80 and propylene glycol $(1: 1)]\left(5 \mathrm{~mL} \mathrm{~kg}^{-1}\right)$, or cimetidine $(100$ $\left.\mathrm{mg} \mathrm{kg}{ }^{-1}\right)$. After $30 \mathrm{~min}$, ulcers were induced by oral administration of indomethacin $40 \mathrm{mg} \mathrm{kg}^{-1}$. Animals were sacrificed by an overdose of chloroform $8 \mathrm{~h}$ later. The stomachs were removed, opened along the greater curvature and rinsed under a stream of water. Erosions formed on the glandular portion of the stomach were observed and each graded on a (0-3) scale based on the length of the ulcer; $0=$ normal; $1=\langle 1 \mathrm{~mm} ; 2=1-2$ $\mathrm{mm} ; 3=>2 \mathrm{~mm}$ (Main and Whittle, 1975). Mean ulcer score for each group was calculated and expressed as the Ulcer Index (UI). Ulcer protection (\%) was calculated using the relation:

$$
\text { Ulcer protection }(\%)=100[1-\mathrm{y} / \mathrm{z}]
$$

Where:

$\mathrm{y}=$ Ulcer index of treated group

$\mathrm{Z}=$ Ulcer index of control group (Ezike et al., 2009)

\subsection{Antibacterial Activity Tests}

The extract and fractions were evaluated for antibacterial activity against clinical isolates of Bacillus cereus, Escherichia coli, Pseudomonas aeruginosa and Salmonella typhi using the agar well diffusion method (Lovian, 1980).

\subsection{Bacterial Sensitivity Test}

Briefly, sterile petriplates containing molten nutrient agar were seeded with $0.1 \mathrm{~mL}$ standardized broth culture $\left(1 \times 10^{6} \mathrm{cfu} \mathrm{\textrm {mL } ^ { - 1 } )}\right.$ of the bacteria. When set, the test substances $\left(100 \mathrm{mg} \mathrm{mL}^{-1}\right)$ were introduced into the respective wells bored on the agar by means of a sterile cork borer (6 $\mathrm{mm}$ diameter). Thirty minutes later, the plates were incubated in an inverted position for $24 \mathrm{~h}$ at $37^{\circ} \mathrm{C}$, after which the Inhibition Zone Diameter (IZD) was measured. Gentamycin was used as reference standard and tests were done in triplicates. The growth of B. cereus, $P$. aeruginosa, E. coli and $S$. typhi were appreciably 
inhibited by DVE. Thus, DVE was subjected to minimum inhibitory concentration (MIC) determination.

\subsection{Determination of Minimum Inhibitory Concentration (MIC)}

The procedure described above was also adopted, using $100,50,25,12.5,6.25$ and $3.125 \mathrm{mg} \mathrm{mL}^{-1}$ of DVE and the respective IZD determined. Tests were performed in triplicates. Subsequently, the Minimum Inhibitory Concentration (MIC) was determined as antilog of the intercept on the concentration axis of log concentration against mean $\mathrm{IZD}^{2}$ plot.

\subsection{Statistical Analysis}

The data obtained were analyzed using one way ANOVA (SPSS version 16.0) and expressed as mean \pm Standard Error of Mean (SEM). The difference between means of treatment and control groups were further evaluated using LSD post hoc test.

\section{RESULTS}

\subsection{Acute Toxicity and Lethality $\left(\mathbf{L D}_{\mathbf{5 0}}\right)$}

Oral administration of DVE caused no death at 10$5000 \mathrm{mg} \mathrm{kg}^{-1}$. The oral $\mathrm{LD}_{50}$ of DVE in mice was thus established to be greater than $5,000 \mathrm{mg} \mathrm{kg}^{-1}$.

\subsection{Phytochemical Constituents of Extract and Fractions}

Preliminary phytochemical analysis showed that DVE and DVMF tested positive to alkaloids, saponins, flavonoids, terpenoids, steroids, resins. DVHF gave positive reactions for terpenoids and resins, while DVDF tested positive to flavonoids, alkaloids, steroids, terpenoids and resins.

\subsection{Effect of Extract and Fractions on Normal Defecation}

The extract and fractions significantly $(\mathrm{p}<0.05)$ reduced the number of fecal boli produced by normal rats at $1 \mathrm{~h}$. The DVDF treated rats did not excrete any feces up to $4 \mathrm{~h}$. The DVDF (200 and $400 \mathrm{mg} \mathrm{kg}^{-1}$ ), DVHF (400 mg $\mathrm{kg}^{-1}$ ) and DVMF (200 $\mathrm{mg} \mathrm{kg}^{-1}$ ) elicited $100 \%$ inhibition of normal defecation in average time of $4 \mathrm{~h}$, while DVE (200 and $400 \mathrm{mg} \mathrm{kg}^{-1}$ ), DVHF (200 mg kg-1), DVMF (400 $\mathrm{mg} \mathrm{kg}^{-1}$ ) and loperamide caused 33.33, 55.00, 88.89, 0.00 and $88.89 \%$ inhibition respectively in the same time.

\subsection{Effect of Extract and Fractions on Castor Oil Induced Diarrhea}

Four hours after castor oil administration, all the rats in the control group produced copious diarrhea. Pretreatment with extracts and fractions elicited significant $(\mathrm{p}<0.05-0.001)$ and dose-related delay in the onset of diarrhea, reduction in the frequency of defecation and the wetness of the fecal droppings (as shown by reduction in the number of total and wet stools) (Table 1). The extract and fractions elicited significant $(\mathrm{p}<0.05-0.001)$ and dose-related reduction in number of wet feces in rats with castor oil induced diarrhea up to $5 \mathrm{~h}$, with DVDF (200 and $400 \mathrm{mg} \mathrm{kg}^{-1}$ ) and DVMF (200 $\mathrm{mg} \mathrm{kg}^{-1}$ ) causing $100 \%$ inhibition. The magnitude of inhibition was of the order DVDF $>$ DVMF $>$ DVHF $>$ DVE (Table 1).

\subsection{Effect of Extract and Fractions on Gastrointestinal Propulsion}

The extract and fractions elicited significant $(\mathrm{p}<0.05)$ dose-related reduction in charcoal meal transit time. The DVE and DVDF (400 $\mathrm{mg} \mathrm{kg}^{-1}$ ), reduced the distance covered by the charcoal meal in the gastrointestinal (GI) tract of mice by $41.56 \%$ and $48.88 \%$ respectively. These values were higher than $35.61 \%$ produced by atropine $\left(10 \mathrm{mg} \mathrm{kg}^{-1}\right)$. The magnitude of inhibition was of the order DVDF $>$ DVE $>$ DVHF $>$ DVMF (Table 2).

\subsection{Effect of Extract and Fractions on the Isolated Guinea Pig Ileum}

The extract and fractions neither contracted nor relaxed the isolated guinea pig ileum. However, they inhibited contractions induced by acetylcholine and histamine to varying extents.

The DVE inhibited acetylcholine-induced contractions of the guinea pig ileum at increasing doses from $0.02 \mathrm{mg} \mathrm{mL}^{-1}$. Peak inhibition of $75 \%$ was produced by $12.8 \mathrm{mg} \mathrm{mL}^{-1}\left(\mathrm{IC}_{50}=7.94 \mathrm{mg} \mathrm{mL}^{-1}\right)$ (Fig. 1). DVHF produced a non-dose related inhibition with $6.4 \mathrm{mg} \mathrm{mL} \mathrm{mL}^{-1}$ eliciting $42.13 \%$ inhibition. Peak inhibition $(42.27 \%$ ) was produced by $1.6 \mathrm{mg} \mathrm{mL}$ (data not shown). DVDF inhibited acetylcholine-induced contractions of the guinea pig ileum at increasing doses from $0.20 \mathrm{mg} \mathrm{mL}^{-1}$. Peak inhibition of $91.25 \%$ was produced by $1 \mathrm{mg} \mathrm{mL}^{-1}$ $\left(\mathrm{IC}_{50}=0.38 \mathrm{mg} \mathrm{mL}^{-1}\right)$ (Fig. 1). DVMF $\left(1.6 \mathrm{mg} \mathrm{mL}^{-1}\right)$ gave $100 \%$ inhibition $\left(\mathrm{IC}_{50}=0.33 \mathrm{mg} \mathrm{mL}^{-1}\right)$ (Fig. 1). 


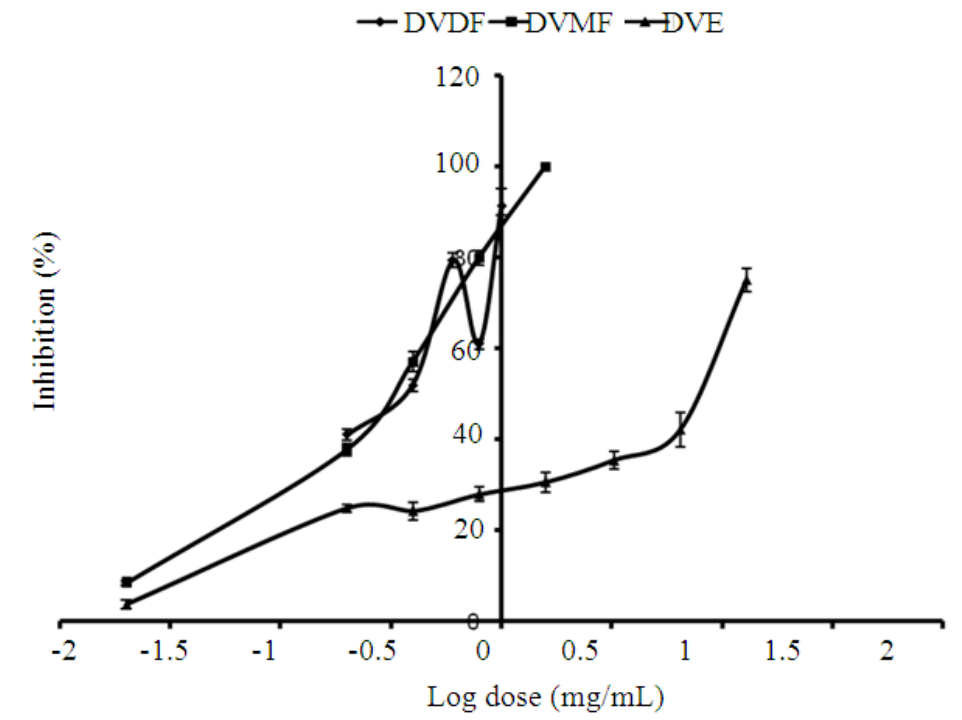

Fig. 1. Effect of D. velutinum extract and fractions on acetylcholine $\left(0.64 \mu \mathrm{g} \mathrm{mL} \mathrm{L}^{-1}\right)$-induced contractions of the guinea pig ileum

Table 1. Effect of D. velutinum extract and fractions on castor oil induced diarrhea

\begin{tabular}{lllllll}
\hline Treatment & $\begin{array}{l}\text { Dose } \\
\left(\mathrm{mg} \mathrm{kg}^{-1}\right)\end{array}$ & $\begin{array}{l}\text { No. of rats } \\
\text { with diarrhea }(\%)\end{array}$ & $\begin{array}{l}\text { Rats } \\
\text { protected }(\%)\end{array}$ & $\begin{array}{l}\text { Total no. } \\
\text { of stools }\end{array}$ & $\begin{array}{l}\text { No. of } \\
\text { wet stools }\end{array}$ & $\begin{array}{l}\text { No. of } \\
\text { dry stools }\end{array}$ \\
\hline DVE & 200 & $3 / 5(60)$ & 40 & $2.2 \pm 1.02$ & $1.4 \pm 0.75$ & $0.8 \pm 0.58$ \\
& 400 & $1 / 5(20)$ & 80 & $0.8 \pm 0.8^{\mathrm{a}}$ & $0.8 \pm 0.8^{\mathrm{a}}$ & $0.0 \pm 0.0$ \\
DVHF & 200 & $2 / 5(40)$ & 60 & $2.0 \pm 1.14$ & $0.6 \pm 0.4^{\mathrm{b}}$ & $1.4 \pm 0.75$ \\
& 400 & $1 / 5(20)$ & 80 & $0.6 \pm 0.6^{\mathrm{a}}$ & $0.2 \pm 0.2^{\mathrm{c}}$ & $0.4 \pm 0.4$ \\
DVDF & 200 & $0 / 5(0)$ & 100 & $0.0 \pm 0.0^{\mathrm{b}}$ & $0.0 \pm 0.0^{\mathrm{c}}$ & $0.0 \pm 0.0$ \\
& 400 & $0 / 5(0)$ & 100 & $0.0 \pm 0.0^{\mathrm{b}}$ & $0.0 \pm 0.0^{\mathrm{c}}$ & $0.0 \pm 0.0$ \\
DVMF & 200 & $0 / 5(0)$ & 100 & $0.0 \pm 0.0^{\mathrm{b}}$ & $0.0 \pm 0.0^{\mathrm{c}}$ & $0.0 \pm 0.0$ \\
& 400 & $2 / 5(40)$ & 60 & $1.0 \pm 0.8^{\mathrm{a}}$ & $1.0 \pm 0.77^{\mathrm{a}}$ & $0.0 \pm 0.0$ \\
Loperamide & 2 & $1 / 5(20)$ & 80 & $1.4 \pm 1.4$ & $0.6 \pm 0.6^{\mathrm{b}}$ & $0.8 \pm 0.8$ \\
Control & - & $5 / 5(100)$ & 0 & $3.4 \pm 0.81$ & $2.8 \pm 0.73$ & $0.6 \pm 0.24$ \\
\hline
\end{tabular}

$\mathrm{n}=5 ;{ }^{\mathrm{a}} \mathrm{p}<0.05,{ }^{\mathrm{b}} \mathrm{p}<0.01,{ }^{\mathrm{c}} \mathrm{p}<0.001$ compared to control (ANOVA; LSD post hoc test); DVE = crude extract; DVHF = hexane fraction; DVDF = dichloromethane fraction; DVMF = methanol fraction

Table 2. Effect of D. velutinum extract and fractions on gastrointestinal propulsion

\begin{tabular}{lllllr}
\hline Treatment & $\begin{array}{l}\text { Dose } \\
\left(\mathrm{mg} \mathrm{kg}^{-1}\right)\end{array}$ & $\begin{array}{l}\text { Total length of } \\
\text { intestine }(\mathrm{cm})\end{array}$ & $\begin{array}{l}\text { Distance traversed by } \\
\text { charcoal meal }(\mathrm{cm})\end{array}$ & $\begin{array}{l}\text { Propulsion } \\
(\%)\end{array}$ & $\begin{array}{l}\text { Inhibition of } \\
\text { propulsion }(\%)\end{array}$ \\
\hline DVE & 200 & $43.90 \pm 2.90$ & $25.10 \pm 4.70$ & 56.95 & 0.63 \\
& 400 & $45.20 \pm 2.78$ & $14.46 \pm 2.90$ & $31.77^{*}$ & 41.56 \\
DVHF & 200 & $43.80 \pm 4.79$ & $18.40 \pm 3.36$ & $41.83 *$ & 27.01 \\
& 400 & $44.68 \pm 3.43$ & $24.60 \pm 0.89$ & 55.22 & 3.65 \\
DVDF & 200 & $53.10 \pm 6.99$ & $21.70 \pm 9.07$ & $40.56^{*}$ & 29.23 \\
& 400 & $46.12 \pm 3.29$ & $13.56 \pm 3.29$ & $29.33^{*}$ & 48.88 \\
DVMF & 200 & $44.44 \pm 1.08$ & $19.82 \pm 8.98$ & $44.51^{*}$ & 3.18 \\
& 400 & $43.84 \pm 2.15$ & $23.48 \pm 3.74$ & 33.51 & 8.63 \\
Atropine & 10 & $47.14 \pm 4.23$ & $17.38 \pm 2.00$ & $57.90^{*}$ & 35.61 \\
Control & - & $46.62 \pm 3.53$ & $26.74 \pm 2.37$ & -
\end{tabular}

$\mathrm{n}=5 ; * \mathrm{P}<0.05$ compared to control (ANOVA; LSD post hoc test); DVE = crude extract; DVHF = hexane fraction; DVDF = dichloromethane fraction; DVMF = methanol fraction 
The order of potency of inhibition of acetylcholineinduced-contractions of the guinea pig ileum was DVMF $>$ DVDF $>$ DVE $>$ DVHF (Table 3). The DVE inhibited histamine-induced contractions at increasing doses from $1 \mathrm{mg} \mathrm{mL}^{-1}\left(\mathrm{IC}_{50}=2.99 \mathrm{mg} \mathrm{mL}^{-1}\right)$ (Fig. 2). DVHF produced varied, inconsistent and erratic effects with $20 \mathrm{mg} \mathrm{mL}$ eliciting $22.2 \%$ inhibition. Peak inhibition of $50 \%$ was produced by $0.2 \mathrm{mg} \mathrm{mL}^{-1}$ (data not shown). DVDF inhibited histamine-induced contractions at increasing doses from $0.20 \mathrm{mg} \mathrm{mL}^{-1}$. Peak inhibition of $100 \%$ was produced by $1 \mathrm{mg} \mathrm{mL}^{-1}$ $\left(\mathrm{IC}_{50}=0.45 \mathrm{mg} \mathrm{mL}\right.$ ) (Fig. 2). DVMF inhibited contractions at increasing doses from $0.40 \mathrm{mg} \mathrm{mL}^{-1}$ with $100 \%$ inhibition achieved with $8.00 \mathrm{mg} \mathrm{mL}^{-1}\left(\mathrm{IC}_{50}=\right.$ $2.66 \mathrm{mg} \mathrm{mL}^{-1}$ ) (Fig. 2). The order of potency of inhibition of histamine induced-contractions of guinea pig ileum was DVDF $>$ DVMF $>$ DVE $>$ DVHF (Table 3).

\subsection{Effect of Extract and Fractions on Rhythmic \\ Contractions of the Rabbit Jejunum}

The DVE inhibited rhythmic contractions of the rabbit jejunum at increasing doses from $0.2 \mathrm{mg} \mathrm{mL}^{-1}$. Peak inhibition of $58.83 \%$ was produced by $6.4 \mathrm{mg} \mathrm{mL}^{-1}\left(\mathrm{IC}_{50}\right.$ $=3.35 \mathrm{mg} \mathrm{mL}^{-1}$ ) (Fig. 3). DVHF inhibited rhythmic contractions at increasing doses from $0.4 \mathrm{mg} \mathrm{mL}^{-1}$. Peak inhibition of $55.50 \%$ was produced by $6.4 \mathrm{mg} \mathrm{mL}^{-1}\left(\mathrm{IC}_{50}\right.$ $=3.55 \mathrm{mg} \mathrm{mL}^{-1}$ ) (Fig. 3). DVDF inhibited rhythmic contractions at increasing doses from $2 \times 10^{-3} \mathrm{mg} \mathrm{mL}^{-1}$.
Peak inhibition of $100 \%$ was produced by $3.2 \mathrm{mg} \mathrm{mL}^{-1}$ $\left(\mathrm{IC}_{50}=0.58 \mathrm{mg} \mathrm{mL}^{-1}\right.$ (Fig. 3). DVMF inhibited rhythmic contractions at increasing doses from $0.20 \mathrm{mg} \mathrm{mL}^{-1}$ with a peak inhibition of $90.91 \%$ occurring at $3.2 \mathrm{mg} \mathrm{mL}^{-1}\left(\mathrm{IC}_{50}\right.$ $=0.71 \mathrm{mg} \mathrm{mL}{ }^{-1}$ ) $($ Fig. 3). The order of potency of inhibition of rhythmic contraction of rabbit jejunum was DVDF $>$ DVMF $>$ DVE $>$ DVHF.

\subsection{Effect of Extract and Fractions on Ethanol Induced Ulcer}

They elicited a dose dependent and significant $(\mathrm{p}<0.05)$ protection against ethanol induced ulcer with order of magnitude DVDF $>$ DVE $>$ DVHF $>$ DVMF (Table 4). The DVDF and DVE $400 \mathrm{mg} \mathrm{kg}^{-1}$ afforded $100 \%$ protection (Table 4).

\subsection{Effect of Extract and Fractions on Indomethacin Induced Ulcer}

The extracts and fractions afforded little or no protection against indomethacin induced ulcer as shown by the ulcer index (Table 4).

\subsection{Effect of Extract and Fractions on Bacterial Growth}

The DVE inhibited the growth of $B$. cereus, $P$. aeruginosa, E. coli and S. typhi with MICs of 37.15, $39.81,100$ and $100 \mathrm{mg} \mathrm{mL}^{-1}$ respectively.

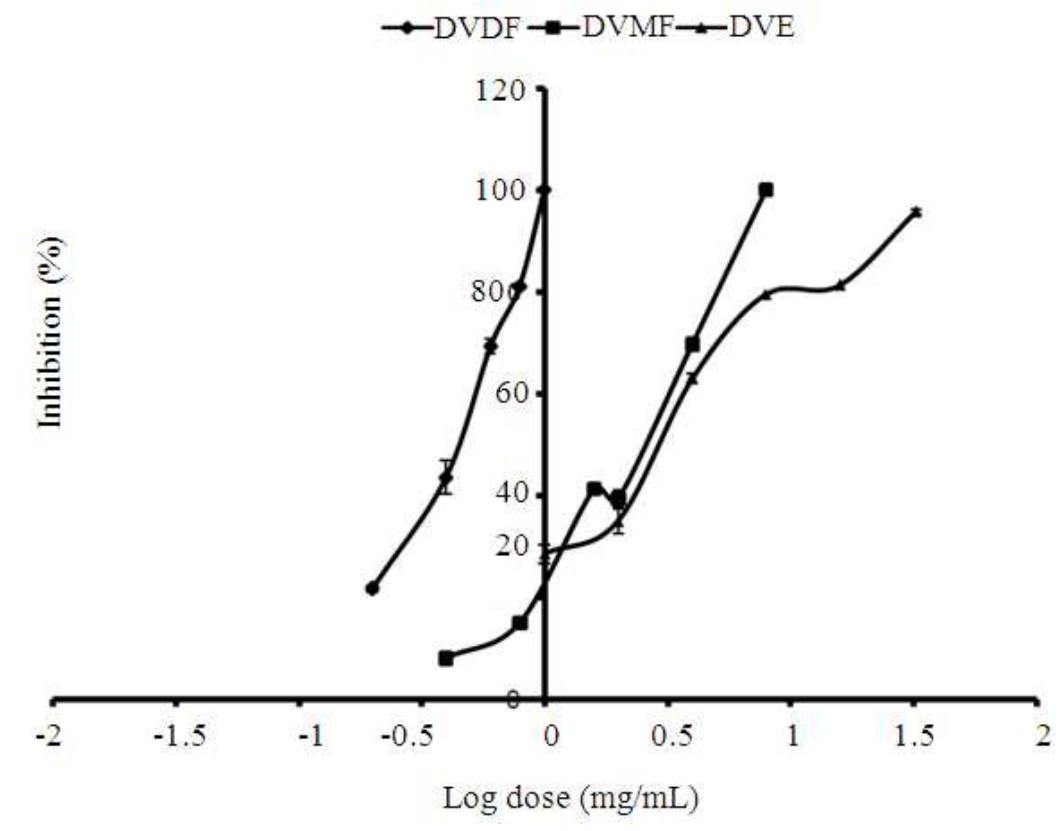

Fig. 2. Effect of D. velutinum extract and fractions on histamine $\left(0.64 \mu \mathrm{g} \mathrm{mL} \mathrm{L}^{-1}\right)$ - induced contractions of the guinea pig ileum 
Ezike, A.C. et al. / American Journal of Pharmacology and Toxicology 9 (2): 114-124, 2014

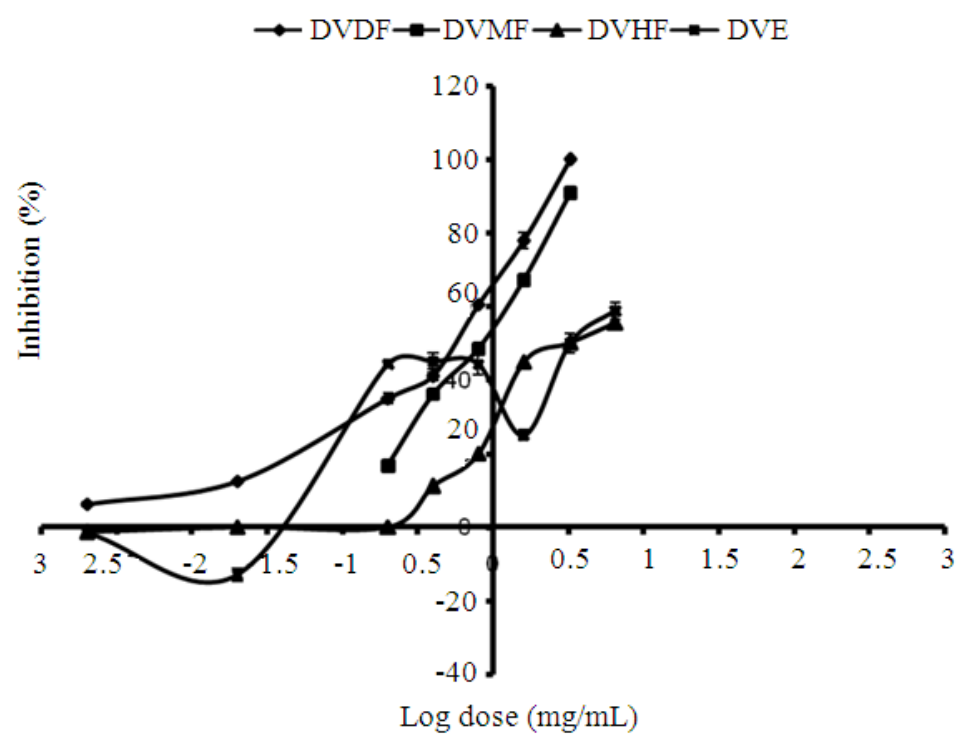

Fig. 3. Effect of $D$. velutinum extract and fractions on intrinsic rhythmic contractions of the rabbit jejunum

Table 3. Inhibitory effect of D. velutinum extracts and fractions on spasmogen-induced contractions of the guinea pig ileum

\begin{tabular}{|c|c|c|}
\hline \multirow[b]{2}{*}{ Extract } & \multicolumn{2}{|l|}{$\mathrm{IC}_{50}\left(\mathrm{mg} \mathrm{mL}^{-1}\right)$} \\
\hline & Acetylcholine & Histamine \\
\hline DVE & 7.94 & 2.99 \\
\hline DVHF & $-^{\mathrm{a}}$ & $-^{\mathrm{a}}$ \\
\hline DVDF & 0.38 & 0.45 \\
\hline DVMF & 0.33 & 2.66 \\
\hline
\end{tabular}

${ }^{\mathrm{a}}$ The $\mathrm{IC}_{50}$ could not be determined with the available data; DVE = crude extract; DVHF = hexane fraction; DVDF = dichloromethane fraction; DVMF = methanol fraction

Table 4. Effects of D. velutinum extract and fractions on gastric ulcers

Ulcer index (\% ulcer protection)

\begin{tabular}{|c|c|c|c|}
\hline \multirow[b]{2}{*}{ Treatment } & \multirow[b]{2}{*}{ Dose $\left(\mathrm{mg} \mathrm{kg}^{-1}\right)$} & \\
\hline & & Ethanol & Indomethacin \\
\hline \multirow[t]{2}{*}{$\overline{D V E}$} & 200 & $\begin{array}{l}2.20 \pm 1.36^{*} \\
(59.26)\end{array}$ & $\begin{array}{l}132.60 \pm 21.83 \\
(\mathrm{NP})\end{array}$ \\
\hline & 400 & $\begin{array}{l}0.00 \pm 0.00 * \\
(100)\end{array}$ & $\begin{array}{l}82.80 \pm 17.59 \\
(24.18)\end{array}$ \\
\hline \multirow[t]{2}{*}{ DVHF } & 200 & $\begin{array}{l}3.40 \pm 0.68 \\
(37.04)\end{array}$ & $\begin{array}{l}95.40 \pm 17.24 \\
(12.64)\end{array}$ \\
\hline & 400 & $\begin{array}{l}0.40 \pm 0.24 * \\
(92.6)\end{array}$ & $\begin{array}{l}88.20 \pm 25.13 \\
(19.23)\end{array}$ \\
\hline \multirow[t]{2}{*}{ DVDF } & 200 & $\begin{array}{l}1.20 \pm 0.97 * \\
(77.78)\end{array}$ & $\begin{array}{l}105.00 \pm 12.44 \\
(3.85)\end{array}$ \\
\hline & 400 & $\begin{array}{l}0.00 \pm 0.00 * \\
(100)\end{array}$ & $\begin{array}{l}114.00 \pm 31.26 \\
(\mathrm{NP})\end{array}$ \\
\hline \multirow[t]{2}{*}{ DVMF } & 200 & $\begin{array}{l}3.00 \pm 1.34 * \\
(44.44)\end{array}$ & $\begin{array}{l}139.80 \pm 28.17 \\
(\mathrm{NP})\end{array}$ \\
\hline & 400 & $\begin{array}{l}5.40 \pm 0.24 \\
(0)\end{array}$ & $\begin{array}{l}157.80 \pm 17.89 \\
(\mathrm{NP})\end{array}$ \\
\hline Cimetidine & 100 & $\begin{array}{l}5.20 \pm 0.20 \\
(3.70)\end{array}$ & $\begin{array}{l}33.40 \pm 17.03 * \\
(69.41)\end{array}$ \\
\hline Control & - & $5.40 \pm 0.68$ & $109.20 \pm 5.89$ \\
\hline
\end{tabular}

$\mathrm{n}=5 ; * \mathrm{p}<0.05$ compared to control (ANOVA; LSD post hoc test); NP = No protection; DVE = crude extract; DVHF = hexane fraction; $\mathrm{DVDF}=$ dichloromethane fraction; $\mathrm{DVMF}=$ methanol fraction; value in parenthesis represent ulcer protection (\%) compared to control 


\section{DISCUSSION}

The study results showed that $D$. velutinum leaf extract and fractions reduced normal defecation in rats, protected rats against castor oil-induced diarrhea, delayed gastrointestinal transit in mice and inhibited spasmogen-induced contractions of the guinea pig ileum and rhythmic contractions of the rabbit jejunum.

The extract and fractions significantly $(\mathrm{p}<0.05)$ reduced the number of fecal boli produced by normal rats at $1 \mathrm{~h}$. The DVDF treated rats did not excrete any feces up to $4 \mathrm{~h}$. This reduction of normal defecation is likely due to interference with GI peristalsis and motility.

Subsequent administration of the extract and fractions to rats with diarrhea experimentally induced with castor oil caused antidiarrheal activity by suppressing the excretion of both total and wet feces. Castor oil induces diarrhea by the actions of its hydrolytic product, ricinoleic acid, which acts primarily in the small intestine to stimulate secretion of fluid and electrolytes, decrease mucosal fluid absorption and increase intestinal motility, ultimately producing fluid and watery luminal contents that flow rapidly through the small and large intestines (Spruill and Wade, 2005). Consistent with this is the significant $(\mathrm{p}<0.05)$ and dose-related reduction in charcoal meal transit time elicited by the leaf extracts. Prolongation of charcoal meal transit time is usually due to antimotility action leading to delay in gastric emptying and reduction in GI propulsion. Inhibition of small intestinal propulsive movement exerts control on diarrhea by preventing speedy evacuation of GI contents. The suppression of total and wet feces production in rats with castor oil induced diarrhea and prolongation of charcoal meal transit time, further demonstrate that the antidiarrheal effect of the $D$. velutinum leaf may derive largely, albeit in part, from reduction of GI motility.

Further studies using isolated GI smooth muscle tissues showed that extracts and fractions neither relaxed nor contracted the guinea pig ileum, but inhibited spasmogen-induced ileal contractions and the spontaneous contractions of the rabbit jejunum. These effects suggest that constituents of the extract and fractions may possess antispasmodic properties known to suppress gut motility. Although the extract and fractions neither contracted nor relaxed the ileum, suppression of spontaneous contractions of the jejunum indicates they may reduce the tone of the normal gut and such action may largely account for the inhibition of normal defecation observed. The motor and secretory functions of the GI tract is regulated through the actions of many excitatory and inhibitory neurotransmitters such as acetylcholine, histamine, tachykinins such as substance $\mathrm{P}$, serotonin, nitric oxide and vasoactive intestinal peptide (Ahlquist and Camilleri, 2005). The release of the excitatory neurotransmitters in the gut causes excitation-contraction coupling in the GI smooth muscles, ultimately mediated through an increase in intracellular $\mathrm{Ca}^{2+}$ concentration (Pasricha, 2006). A substance with the ability to block the effect of any of the above mediators or cause non-specific inhibitory action like antagonism of $\mathrm{Ca}^{2+}$ is likely to be effective in hyperactive gut disorders such as diarrhea. The twin mechanisms of inhibition of spasmogen-induced ileal contractions and spontaneous jejunal contractions suggest that non-specific action may partly account for the antimotility activity of this plant. Antispasmodic actions on gastrointestinal smooth muscles result to reduced motility and propulsion of GI contents, even in the face of spasmogenic effects of luminal contents during diarrhea disease. The reduced GI motility prolongs the stay of luminal contents in the gut thus creating more time for the consequent absorption of water and solidification of fecal matter.

The extract and fractions were also screened for antiulcer effects since a number of synthetic drugs (e.g., muscarinic antagonists) and medicinal plants (Ezike et al., 2011) known to reduce GI motility also exert gastroprotective effects. They elicited a dose dependent and significant $(\mathrm{p}<0.05)$ protection against ethanol induced ulcer, but there was little or no protection against indomethacin induced ulcer. Ethanol, a common ulcerogen, produces severe haemorrhagic erosions in the glandular (mucosal) part of the stomach (Ezike et al., 2009) from mechanisms such as direct toxic action, reduction of the secretion of bicarbonate, depletion of gastric wall mucus (Al-Harbi et al., 1997), stimulation of the synthesis and release of leukotriene $\mathrm{C}_{4}$ (Peskar et al., 1986) and significant production of oxygen free radicals which increase lipid peroxidation and damage cells (Pihan et al., 1987). It also reduces endogenous glutathione and prostaglandin levels and increases the release of histamine, influx of calcium ions and generation of free radicals (Galvin and Szabo, 1992). Thus, the action of the extract and fractions in this model suggests cytoprotective action possibly mediated through enhancement of mucosal defensive factors. Since the extract and fractions inhibited the contractile action of histamine on the isolated ileum, the antihistaminic effect in the gut may contribute to the protection against ethanol-induced ulcers. Indomethacin-induced gastric mucosal damage results mainly from suppression of prostaglandin synthesis via the arachidonic pathway. 
Therefore, the mild protection offered by the extract and fractions against indomethacin-induced ulcers suggests they may mildly enhance the synthesis or inhibit the depletion of prostaglandins. Inhibition of prostaglandin depletion or enhancement of its synthesis elevates its level in the gastric mucosa and may be responsible for the cytoprotective effect of the extract and fractions as well as the mild protection against indomethacin ulceration. It is, however, doubtful if this plant may be useful as antiulcer remedy. Nevertheless, due to the antiulcer activity, extractives from the plant may offer obvious additional benefit to ulcer patients who employ it for treatment of diarrhea.

Diarrhea may be caused by pathogenic organisms such as B.cereus, E.coli, Salmonella spp and Shigella spp. and eradication of such organisms effectively controls the diarrhea. Antibacterial activity tests demonstrated that only DVE exhibited mild antibacterial effect against $B$. cereus, $P$. aeruginosa, E. coli and S. typhi, with MICs of 37.15, 39.81, 100 and $100 \mathrm{mg} \mathrm{mL}^{-1}$ respectively. B. cereus (preformed toxin producer) and $E$. coli (enteropathogenic and enteroadherent) are among the bacteria highly implicated in diarrhea (Ahlquist and Camilleri, 2005). However, whereas antimicrobial activity may contribute to the antidiarrheal activity of the leaf, it may not play a major role.

Acute toxicity and lethality $\left(\mathrm{LD}_{50}\right)$ test on the DVE established an oral $\mathrm{LD}_{50}>5,000 \mathrm{mg} \mathrm{kg}^{-1}$ in mice, indicating a high degree of relative safety. Preliminary phytochemical analysis of the extract and fractions revealed the presence of typical phytoconstituents. Flavonoids, alkaloids, saponins, sterols and triterpenes have been reported to account for the antidiarrheal effects of many plants (Palombo, 2005). Flavonoids have been shown to inhibit spasmogen-induced contractions of smooth muscles (Capasso et al., 1988; Macander, 1986), intestinal secretion and small intestinal transit (Carlo et al., 1993; Viswanathan et al., 1984). The abundance of flavonoids, steroids and terpenoids in the most potent fraction DVDF, indicates that flavonoids, steroids and terpenoids may be largely responsible for the antidiarrheal effects of $D$. velutinum leaf. Our data on phytochemical analysis is too preliminary for a conclusive statement on this; however, identification of the active constituent(s) is ongoing.

\section{CONCLUSION}

This study has demonstrated that constituents of $D$. velutinum leaf possess antidiarrheal, antimotility and antispasmodic effects, mildly supplemented by antibacterial activity. These findings provide a rationale for the use of leaves of this plant in the treatment of diarrhea in traditional medicine practice of southeastern Nigeria.

\section{ACKNOWLEDGEMENT}

Researchers are grateful to Chief (Hon.) Cornel Afuekwe Umeh (Okaaobuluzo Nnobi), for plant collection and information on ethnomedicinal uses of the plant.

\subsection{Declaration of Interest}

Authors declare no conflict of interest.

\section{REFERENCES}

Ahlquist, D.A. and M. Camilleri, 2005. Diarrhea and Constipation. In: Harrison's Principles of Internal Medicine, Kasper, D.L., E. Braunwald, A.S. Fauci, S.L. Hauser and D.L. Lono et al. (Eds.), McGrawHill Medical Publishing Division, New York, ISBN-10: 0071391428.

Akah, P.A., 1989. Purgative potentials of euphorbia heterophylla. Fitoterapia, 60: 45-48.

Akinola, J.O., R.A. Afolayan and S.A.S. Olorunju, 1991. Effects of storage testa colour and scarification method on seed germination of Desmodium velutinum (Willd) DC. Seed Sci. Technol., 19: 156-166.

Al-Harbi, M.M., S. Qureshi, M. Kaza, M.M. Ahmed and M. Atzal et al., 1997. Gastric antiulcer and cytoprotective effect of commiphora molmol in rats. J. Ethnopharmacol., 55: 141-150. DOI: 10.1016/S0378-8741(96)01488-2

Anowi, C.F., A.F. Onyegbule, T. Onyekaba and C. Azode, 2012a. Antipyretic and phytochemical evaluation of the ethanol extract of the leaves of Desmodium velutinum. Asian J. Pharmacy Life Sci., 2: 135-143.

Anowi, C.F., E.E. Ilodigwe, D.L. Ajaghaku and C. Ezennia, 2012b. Evaluation of antidiarrhoea activity of the methanolic and methylenedichloride (50:50) leaf extracts of Desmodium velutinum (Fabaceae). IJPI's J. Pharmacognosy Herbal Formulat., 2: 8-8.

Asare, E.O., T. Shehu and E.A. Agishi, 1984. Preliminary studies on indigenous species for dry season grazing in the northern guinea savanna zone of Nigeria. Tropical Grassland, 18: 148-152.

Awouters, F., C.J.E. Niemegeers, F.M. Lenaerts and P.A.J. Janssen, 1978. Delay of castor oil diarrhoea in rats: A new way to evaluate inhibitors of prostaglandin biosynthesis. J. Pharm. Pharmacol. 30: 41-45. PMID: 22723. 
Capasso, F., A. Pintoy, N. Mascolo, G. Autore and M.P. Franco, 1988. Effects of flavonoids on $\mathrm{PGE}_{2^{-}}$and LTD4- induced contractions on the guinea-pig isolated ileum. Pharmacol.. Res. Commun., 20: 201202. DOI: 10.1016/S0031-6989(88)80711-2

Carlo, D.G., G. Autore, A.A Izzo, P. Maiolino, N. Mascolo et al., 1993. Inhibition of intestinal motility and secretion by flavonoids in mice and rats: Structure-activity relationships. J. Pharmacy Pharmacol., 45: 1054-1059. PMID: 7908974

Ezike, A.C., P.A. Akah, C.O. Okoli, N. A. Ezeuchenne and S. Ezeugwu, 2009. Carica papaya (paw-paw) unripe fruit may be beneficial in ulcer. J. Med. Food, 12: 1268-1273.DOI: 10.1089/jmf.2008.0197

Ezike, A.C., P.A. Akah, C.O. Okoli, N. Udemezue and O. Okoro, 2011. Experimental evaluation of antiulcer and spasmolytic potentials of leaves of Cajanus cajan. Natural Product: An Ind. J.

Galvin, G.B. and S. Szabo, 1992. Experimental gastric mucosal injury: Laboratory models reveal mechanisms of pathogenesis and new therapeutic strategy. FASEB J., 6: 825-831. PMID: 1740232

Harborne, J.B., 1973. Phytochemical Methods. 1st Edn., Toppan Company Tokyo, Japan, pp: 278.

Iwu, M.M., 1978. Practical pharmacognosy manual of natural products. Department Pharmacognosy, University Nigeria.

Izzo, A.A., M. Nicoletti, B. Giannattasio and F. Capasso, 1992. Antidiarrheal Activity of Terminalia Sericea Burch. ex DC Extracts. In: Natural Drugs and the Digestive Tract, Capasso, F. and N. Mascolo (Eds.), EMSI, Rome.

Kosek, M., C. Bern and R.L. Guerrant, 2003. The global burden of diarrhoeal disease, as estimated from studies published between 1992 and 2000. Bull. World Health Organ., 81: 197-204. PMID: 12764516

Lorke, D., 1983. A new approach to practical acute toxicity testing. Archives Toxicol., 54: 275-287. DOI: $10.1007 / \mathrm{BF} 01234480$

Lovian, V., 1980. Antibiotics in Laboratory Medicine. 1st Edt., Williams and Williams, Baltimore, London. ISBN-10: 0683051660, pp: 737.

Macander, P.J., 1986. Flavonoids affect acetylcholine, prostaglandin E2 and antigen-mediated smooth muscle contraction. Progress Clin. Biol. Res., 213: 489-492. PMID: 2872681
Main, I.H.M. and B.J. R. Whittle, 1975. Investigation of the vasodilator and antisecretory role of prostaglandins in the rat gastric mucosa by use of non-steroidal anti-inflammatory drugs. British J. Pharmacol., 53: 217-224. DOI: 10.1111/j.14765381.1975.tb07351.x

Palombo, E.A., 2005. Phytochemicals from traditional medicinal plants used in the treatment of diarrhoea: Modes of actions and effects on intestinal function. Phytotherapy Res., 20: 717-724. DOI: 10.1002/ptr.1907

Pasricha, P.J., 2006. Treatment of Disorders of Bowel Motility and Water Flux; Anti-Emetics; Agents Used in Biliary and Pancreatic Disease. In: Goodman and Gilman's The Pharmacological Basis of Therapeutics, Brunton, L.L., J.S. Lazo and K.L. Parker (Eds.), McGraw-Hill, New York.

Peskar, B.M., K. Lange, U. Hoppe and B.A. Preskar, 1986. Ethanol stimulates formation of leukotriene $\mathrm{C} 4$ in rat gastric mucosa. Prostaglandins, 31: 283293. DOI: 10.1016/0090-6980(86)90054-7

Pihan, G., C.B. Regillo and S. Szabo, 1987. Free radicals and lipid peroxidation in ethanol- or aspirin-induced gastric mucosal injury. Digestive Dis. Sci., 32: 1395-1401. DOI: $10.1007 /$ BF01296666

Robert, A., 1979. Cytoprotection by prostaglandins. Gastroenterology, 77: 761-767. PMID: 38173

Spruill, W.J. and W.E. Wade, 2005. Diarrhea, Constipation and Irritable Bowel Syndrome. In: Pharmacotherapy: A Pathophysiologic Approach, Matzke, G.R., B.G. Wells and M.L. Possey (Eds.), McGraw-Hill Medical Publishing Division, New York.

Thapar, N. and I.R. Sanderson, 2004. Diarrhoea in children: An interface between developing and developed countries. Lancet, 363: 641-653. PMID: 14987892

Trease, G.E. and W.C. Evans, 1996. Textbook of Pharmacognosy. 14th Edn., W.B. Saunders Company Ltd, London.

Urishidani, T., Y. Kashiya and S. Okabe, 1979. The mechanism of aggravation of indomethacin-induced gastric ulcer by adrenalectomy in rats. Japanese J. Pharmacol., 29: 775-780. DOI: 10.1254/jjp.29.775

Viswanathan, S., S.P. Thirugnana, J. S. Bapha and L. Kameswaran, 1984. Flavonoid-induced delay in the small intestinal transit: Possible mechanism of action. Archives Int. Pharmacodynamie Therapie. 270: 151-157. PMID: 6497500 